\title{
Becoming Pedagogical: Sustaining Hearts With Living Credos
}

\author{
Carl Leggo and Rita L. Irwin \\ University of British Columbia
}

\section{Author Note}

Carl Leggo, Faculty of Education, University of British Columbia, Vancouver, B.C. Rita L. Irwin, Faculty of Education, University of British Columbia.

The research for this article was funded by Social Sciences and Humanities Research Council of Canada (SSHRC). We wish to thank SSHRC for the generous support of our research program.

Correspondence concerning this article should be addressed to Carl Leggo, Email: carl.leggo@ubc.ca or Rita L. Irwin, E-mail: rita.irwin@ubc.ca

\begin{abstract}
From September to December 2009, a class of teacher candidates completed a Bachelor of Education course titled English Language Arts: Secondary Curriculum and Instruction. The instructor introduced himself at the beginning of the course as an a/r/tographer who is an artist, a researcher, and a teacher. He invited students to think about the possibilities of their being a/r/tographers, and to think about how they live in the world, as well as in their new emerging identities in the Bachelor of Education program, as artists and researchers and teachers. The teacher candidates were invited to think about how they were becoming pedagogical, and how they could sustain their hearts in the dynamic and complex process of becoming pedagogical.

They were reminded that teacher candidates are not learning a toolbox of skills and strategies for teaching; they are learning how to navigate the tangled and complex world of human beings in communities called schools.
\end{abstract}

Keywords: teacher education; lifewriting; a/r/tography; credo; creativity 


\section{Becoming Pedagogical: Sustaining Hearts With Living Credos}

In our rush to reform education, we have forgotten a simple truth: reform will never be achieved by renewing appropriations, restricting schools, rewriting curricula, and revising texts if we continue to demean and dishearten the human resource called the teacher on whom so much depends...if we fail to cherish-and challenge-the human heart that is the source of good teaching. [italics added](Palmer, 1998, p. 3)

Teacher education research has become infused with diverse and rigorous studies seeking to raise the standards of teaching and learning through greater attention being paid to teaching efficiency and effectiveness (e.g., Hargreaves, 2000). Day (2008) recognized this focus among policy makers when he reported on the VITAE Project, a 4-year research project that examined a variety of factors influencing the effectiveness of over 300 teachers in over 100 schools. This study reported a wide range of data and analyzed a reform effort in the UK. From our perspective, it vividly illustrated the unfortunate consequences of performativity agendas, and brought to the forefront the continuing need for encouraging educators to be active inquirers in educational contexts. It also highlighted the need for "teachers' sense of identity-the emotional context of their work” (Day, 2008, p. 249). His study provided portraits of educators' self-knowledge, and demonstrated how their conceptions of self are intimately connected to their professional performance. The project revealed that teacher identity is situated across personal, professional, and contextual dimensions, and that teacher commitment is "one of the most critical factors in the success of education" (Day, 2008, p. 254). He also claimed that commitment is a teacher's affective or emotional response to his or her own experiences and is central to the ultimate performance of educators (see also Crosswell, 2006, p. 109). Thus, rather than focusing our attention on teaching effectiveness, teacher educators need to reimagine how we might help teachers sustain their personal and oftentimes, emotional, commitment to teaching and learning.

Through this paper, we hope to inspire many conversations by sharing an alternative approach to practicing and studying teacher education. Building upon Day's (2000, 2008) claims that teacher identity and teacher commitment are central to the success of a teacher's practice, we wanted to explore teaching strategies that might offer teacher candidates a way to consider creatively their identities and commitments to teaching and learning. Our approach positions the teacher candidate as someone learning to learn rather than someone simply learning to teach (Rogers, 2011). While the latter will always play a role in teacher education programs, our recent research with practicing teachers has prompted us to shift our focus to learning to learn. Learning to teach will always be a part of our 12-month after-degree teacher-education program, but shifting to learning to learn has allowed us to concentrate on an inquiry-based approach to teacher education. Moreover, as artists and educators, we use a/r/tography, a hybrid form of practice-based action research that draws upon the identities and practices of artists, researchers, and educators engaged in inquiry that pursues artistic and pedagogical sensibilities and capabilities (Springgay, Irwin, Leggo, \& Gouzouasis, 2008). Our research with practicing educators taught us that a/r/tography provides the relational conditions for making rich intellectual connections between inquiry as research, inquiry as a pedagogical strategy, and inquiry as a creative activity. Because all three forms of 
knowing are acknowledged and valued within a/r/tographic practices, teachers were able to engage in personally meaningful, ongoing, and dialogic forms of professional development. This was an unanticipated finding and demonstrated for us the importance of using artistic strategies in learning to learn and when educators use artistic practices in their own learning, they may be more inclined to experiment with such strategies with their own students.

In this study, we take what we have learned from our previous work with practicing educators and shift our focus to teacher candidates. Moreover, we restate Rogers' (2011) concept of "learning to learn" as becoming pedagogical to connote a state of embodied, living inquiry whereby the learner is committed to learning in and through time. This living inquiry is about becoming pedagogical as the teacher candidate questions and re-imagines his or her intentions and actions as they relate to contextual artefacts and experiences acquired before and during the teacher education program. Processes of making and performing identities transform the idea of learning into becoming pedagogical. This is especially important as teacher candidates engage with their own personal and social aspects of knowing. Living inquiry may be conceived as practice-based action research, and when artistic strategies are included, may be conceived as $\mathrm{a} / \mathrm{r} /$ tography. By conceptualizing the identity of the teacher candidate as a researcher (see Britzman, 2003), living inquiry becomes a place for the teacher candidate to learn skills of observation, questioning, analysis, and interpretation. Teacher candidates acquire those skills as they move from desiring to be a teacher as expert to becoming a teacher as inquirer. As Britzman (2003) found, and our studies concur, because "teachers view their work as research, it becomes more difficult to take the dynamics of classroom life for granted” (p. 239). Becoming pedagogical is an active, living inquiry whereby teachers are in a continuous process of inquiry, engagement, and learning as pedagogues. Yet this study goes even further. A/r/tography offers a materiality, a physicality, which is not addressed by many teacher education researchers. Action research is often employed in teacher education programs as a way of encouraging inquiry. Our approach employs $\mathrm{a} / \mathrm{r} /$ tography as a hybrid form of action research that embraces the arts and education as forms of inquiry (Leggo, Sinner, Irwin, Pantaleo, Gouzouasis, \& Grauer, 2010). In doing so, becoming pedagogical includes a shift from desiring to be an educator as expert to becoming an educator as inquirer and a shift from desiring to be an artist as expert to becoming an artist as inquirer. Learning entails change on multiple levels across multiple identities. The complexities of becoming pedagogical as an English educator must include a shift in understanding oneself as a pedagogue, and as a pedagogue who is also a writer/artist.

To address the long tradition of complex debates about the influence of the humanities in education, Bullough (2006) wrote that "historically, within the field of education, the humanities have been the keepers of the emancipatory aim, part of a grand moral tradition and social ambition” (p. 6). In agreement with Bullough's observation, our research in teacher education, informed by a/r/tography and becoming pedagogical, seeks to address questions like the following: Can teacher education programs foster imagination in learning, living, and becoming? How might a/r/tography promote affective, transformative, integral, holistic, ecological, spiritual, radical, and critical practices and policies of pedagogy? What kinds of teachers are needed for contemporary 
schools? What kind of teacher education is needed in order to help nurture the kind of teachers that are needed? Can a/r/tography contribute to nurturing the kind of teachers that are needed? If so, how?

From September to December 2009, a class of teacher candidates at the University of British Columbia completed a Bachelor of Education course titled English Language Arts: Secondary Curriculum and Instruction. As the instructor, I (Carl) introduced myself at the beginning of the course as an a/r/tographer, an artist, a researcher, and a teacher. I invited students to think about the possibilities of their being $\mathrm{a} / \mathrm{r} /$ tographers, and to think about how they live in the world, as well as in their new emerging identities in the Bachelor of Education program, as artists, researchers, and teachers. The teacher candidates were invited to think about how they were becoming pedagogical, and how they could sustain their hearts in the dynamic and complex process of becoming pedagogical. In presenting the concept of becoming pedagogical, it was necessary to interrogate the denotations and connotations of the phrase. In thinking about becoming pedagogical, the teacher candidates and I (Carl) needed to think about becoming and pedagogical, pedagogical becoming, and becoming pedagogy. For example, we needed to consider the question: Is the focus on the teacher candidates becoming something they are not, or is the focus on their revising and transforming pedagogy? In addition, I quickly realized that I needed to consider carefully how I might be thinking too much about what becoming pedagogical meant to me, and too little about what it meant to the teacher candidates. This emerging challenge reminded everyone in the class that becoming pedagogical is a complex process that includes personal, professional, and political perspectives, contexts, experiences, and identities.

In "Learning-to-Learn and Learning-to-Teach: The Impact of Disciplinary Subject Study on Student-Teachers' Professional Identity," Rogers (2011) argued that while teacher education programs ought to make "available a highly valued repertoire of practical skills," they "should also communicate an accessible set of personal values and vision in learning and teaching which help to inform and shape the professional identities of new teachers" (p. 250). Our research seeks to understand how to promote and support the development of "values and vision" for both teacher candidates and teacher educators. We want to promote a vibrant and vital teacher education experience that invites both creative and critical attention to remembering the past, attending to the present, and imagining the future. Above all, we want a teacher education experience that is transformative where complexity is embraced in the hope for ongoing change, for becoming pedagogical. Of course, this process will be unsettling and challenging. It will be akin to a creative process where the result, product, or performance cannot be formulaic, predictable, or guaranteed. Therefore, teacher candidates are not learning a toolbox of skills and strategies for teaching; they are learning how to navigate the tangled and complex world of human beings in communities called schools. We are putting a focus on teacher candidates as artists, researchers, and teachers because we see the pressing need to acknowledge how teacher candidates need to enter the profession of teaching with the same values, predispositions, approaches, and commitments that artists and researchers bring to their creative and critical work. We invite them to consider how they could sustain their hearts in the dynamic and complex process of becoming pedagogical. Sustaining one's heart is about making passion essential. We agree with 
Day (2005) who wrote, "to be passionate about teaching is not only to express enthusiasm but also to enact it in a principled, values-led, intelligent way” (p. 12). There are no simple answers, no simple solutions, and no fail-safe strategies for either teaching or teaching teachers.

As a part of the course requirements, ${ }^{1}$ the teacher candidates wrote three statements or credos in which they reflected on what they believed about teaching in general, and English teaching in particular. They wrote a brief statement at the beginning of the course, followed by longer statements in the middle and at the end of the course. The teacher candidates were invited to expand on their initial statements, and to continue revising their statements so they could incorporate their responses to the curricular and pedagogical experiences they had encountered in the course and in their 2-week teaching practicum in schools.

Like Cooper and White (2004) in Burning Issues: Foundations of Education, the purpose of the credo assignment was to focus “on understanding how teachers' personal lives influence and inform their professional lives” (p. xii). Cooper and White (2004) recommend that teacher candidates need to begin with their "own lived experiences" (p. xii) in order to "reconnect teachers' personal and professional lives through a process of critical inquiry" (p. xxii) that motivates teacher candidates to consider cosmopolitan contexts that extend far beyond any person's limited experience.

At the beginning of the course, I (Carl) explained to the teacher candidates that the word credo means I believe, but that it also more accurately signifies what I have given my heart to. I explained that both beginning and experienced educators need to ask: What have I given my heart to? As the Dean of State Teachers College in Minot, North Dakota, Flaum published A Credo for Teachers in 1959. Teachers have always written credos, and Flaum's (1959) advice continues to resonate more than half a century later (even if the exclusive pronouns date his words):

The teacher possesses an inquiring mind whose curiosity is disciplined and whose interests are strongly motivated so that he is richer because of his continuous search to create. He helps others in their efforts to create and is appreciative of their talents. (p. 422)

Paying attention to one's credo is not self-indulgent, but it is a way to attend to the complex contexts in which all are socialized, and continue to be socialized. Meijer, de Graaf, and Meirink (2011) spell out three general issues that inform the processes of teacher education, especially the process of learning to teach or to be a teacher. These issues are well understood, but they still can bear repetition and ongoing research. First, teacher candidates "need to deal with their own preconceptions of teaching constructed during the many years of being a student” (Meijer, de Graaf, \& Meirink, 2011, p. 116). Moreover, teacher candidates "need to learn to 'enact' or act out what they know" (Meijer, de Graaf, \& Meirink, 2011, p. 116). Finally, teacher candidates "need to take control of their own learning in order to understand and address the complexity of teaching” (Meijer, de Graaf, \& Meirink, 2011, p. 116). Meijer, de Graaf, and Meirink (2011) present these three issues as well researched in the scholarly literature of teacher education, but their main thesis is that how teacher candidates themselves perceive the 
process “is largely unknown” (Meijer, de Graaf, \& Meirink, 2011, p. 116). Our research is a part of that process of seeking to determine how teacher candidates understand and experience the process of becoming pedagogical. In Pedagogy of the City, Freire (1993) eloquently expresses our understanding of the teacher-researcher: "I think the role of a consciously progressive educator is...to stimulate doubt, criticism, curiosity, questioning, a taste for risk taking, the adventure of creating” (p. 50). Therefore, we invite teacher candidates to engage in researching their daily experiences by writing creatively about their lived experiences, perspectives, and hopes in order to pursue creative processes of transformation.

In order to invite (or incite) teacher candidates in the course to ruminate on the experiences and hopes that fired their credos as beginning teachers, I shared the following narrative account of my own beginning as a school teacher:

I began my first teaching position when I was 22 years old, in 1976 at R. W. Parsons Collegiate in Roberts' Arm, Newfoundland. For 2 years, I was the Grade 7 homeroom teacher, responsible for all curricular disciplines except science. When I recall my experiences as a beginning teacher, I remember, somewhat guiltily, that generally I didn't feel like I was a very good teacher. I felt illprepared. I didn't know enough to be a teacher! Above all, I felt like an impostor, a young man dressed in a tweed sport jacket and gray flannel trousers and colourful necktie from Tip Top Tailors. I looked like a teacher-at least the image of the teacher I thought I should imitate. But, I knew I was an impostor. I didn't feel like a teacher. At least, I didn't feel like I thought I should feel. I lived in fear much of the time. I felt constantly and urgently that I needed so much practice and support. Of course, I did, and the only way to get the practice was to teach, to live daily the demanding role of being a teacher, to grow into my gifts as a teacher, to continue learning how to teach, and how to be a teacher. Essentially, the beginning teacher is thrown into the chaos of the classroom with at least hundreds of demands regarding planning, curriculum, time management, discipline, instructional strategies, technology, and negotiations with pupils, principals, and parents. I was eager to be a good teacher, but the challenge of teaching is always how to live creatively amidst the myriad demands.

Now, I understand that I was a teacher in process, a teacher-researcher, searching again and again my practices and experiences in order to grow in confidence, skills, and imagination. I was engaged in a long process of becoming pedagogical. Twenty-five years after I began my teaching career, I returned to Roberts' Arm for a reunion of teachers and students. During the reunion, I met several former students who were eager to tell me that I had been a favourite teacher, and I heard stories that encouraged me that even though I was not the idealized teacher I hoped to be, I had definitely served some students well. As a beginning teacher, I wavered between feeling powerless and powerful. On the one hand, I assumed that I was in control in the classroom; I was the primary decisionmaker. But, on the other hand, I typically expected educational experts to tell me what I should do. I depended on the stipulations of school administrators, the publications of professors, and the professional development workshops of school district consultants to guide, convince, and inspire me in my teaching. Now, that I 
have been a professor for a long time, I realize that as a beginning teacher I was recapitulating the kind of schooling that I had grown up with, an experience of schooling that assumes that I needed a lot of filling up, and programming, and realigning, and re-energizing. Much like a trolley car in a roller coaster. And, now that I've been a professor for a long time, I also know that professors don't really know very much. They might profess a lot, but they know the searching is always in process, returning to the beginning of the search again and again in order to know the quest(ion)s in lively other ways.

So, I now promote a conception of teachers as teacher-researchers. I invite teachers to engage with action research, teacher inquiry, narrative inquiry, and arts-based inquiry. I want teachers to know themselves as poets. Teachers are not functionaries, and they are not puppets. Teachers are like poets or artists. They improvise, explore, experiment, and practice. Above all, they live their vocation. As Sawyer (2004) understands, "the best teachers apply immense creativity and profound content knowledge to their jobs, both in advance preparation and from moment to moment while in the classroom” (p. 12). (Leggo, personal communication, September 11, 2009)

Five teacher candidates in the course agreed to join the research project, and so this essay focuses on the writing of these five teacher candidates. ${ }^{2}$ It is not our intention to present an exhaustive overview of the concerns and issues that the teacher candidates addressed in the course of their Bachelor of Education studies. What we present here are snapshots, portraits, and images of the process of becoming pedagogical. ${ }^{3}$

\section{Abby's Credo}

At the beginning of the semester, Abby wrote:

I consider my journey towards becoming a teacher as being a series of life experiences, and will continue of course throughout my career as I learn from students, parents, and colleagues. I want to be a great teacher, one who is inclusive and open-minded, hopefully thought-provoking and interesting. I'm not a performer; I want to hear my students. I want a classroom that is welcoming and respectful, fun and interesting. I hope to gain a level of confidence in my curriculum organization so that I can concentrate on the students and not obsess about completing all of the requirements. I don't expect everyone to like me, but I do hope that they will like my class. (Credo, September 14, 2009)

Abby understands how she is involved in a journey of "becoming a teacher," and she recognizes how she brings to that continuing journey all of her life experiences. Her initial credo is full of hope and optimism, and while the adjectives she uses to describe the kind of teacher she wishes to be (inclusive, open-minded, thought-provoking, and interesting) and the kind of classroom she plans to create (welcoming, respectful, fun, and interesting) express the familiar hopes of many teachers, Abby also acknowledges a clear sense of who she is as a person who is becoming a teacher. For example, she is not a performer. She is eager to learn from her students as well as their parents and her colleagues. Above all, she is committed to approaching curriculum organization with a confident and creative focus on student-centered learning. In addition, she is realistic, 
understanding that she personally might not be liked by everyone, but that the class experience can still be a fruitful learning experience.

So, at the beginning of her teacher education program, Abby is thinking about becoming pedagogical as a continuation, extension, and expression of whom she is, which is informed by the places she has been. As teacher educators and researchers, we are encouraged by Abby's commitment to acknowledging the intersections of the personal and the professional, and to understanding how teaching is always inextricably connected to being human in the world.

In a second writing on the eve of beginning a mid-term 2-week teaching practicum, Abby continued to write about the influences that helped shape her sense of becoming pedagogical: The children in my family were taught that social justice and equality are indisputable rights regardless of gender, race, or ability" (Credo, October 19, 2009). Abby writes about her father, mother, and brother as significant influences in shaping her identity as a teacher. Her father is "the standard" she aspires "to be as a teacher."

He is a retired professor in Education from the University of Alberta, and I believe that I possess some of the qualities that made him so successful: patience, understanding, a way of reading people that elicits effective communication, and a strong need to nurture and empower. (Credo, October 19, 2009)

In addition, her mother "became an advocate for special needs children" when her "brother was born with a fairly severe intellectual exceptionality" (Credo, October 19, 2009). Continuing to connect her emerging sense of teacher identity to her past personal experiences, Abby also explains:

I acquired another notch in my personal pedagogy belt when I became a parent. My years in retail human resources taught me to categorize adolescents into personality types, but parenting taught me that each one of those personalities was someone's child, and I want every child to experience growth, enjoyment, and opportunity with their education. I know that all children, even the ones who seem intellectually unable to learn, can achieve great things if we measure success on an individual level and encourage them to feel pride in their accomplishments. I enjoy my son's excitement every Monday morning at the beginning of another school week, and I hope to re-create some of that fun and excitement for learning in my own classroom. (Credo, October 19, 2009)

Based on her experiences as a daughter and mother, Abby is convinced that education must be focused on curiosity:

We are born curious and inquisitive about new experiences and knowledge, and that never leaves us, it just becomes dormant. My challenge as a teacher will be to invoke that curiosity and I hope to do so by making their learning experience relevant, respectful and engaging. (Credo, October 19, 2009)

Above all, Abby expresses her conviction about the need to create a classroom community: "I believe in an environment that elicits the experience of the classroom 
community, and encourages the diverse resources and knowledge that each student possesses" (Credo, October 19, 2009).

She understands how important the teacher is in creating that sense of community:

The teachers that I remember as an adult are those who engaged me, who believed in me, and who created a supportive, safe, and fun atmosphere. (Credo, October 19, 2009)

In a final credo statement, written at the end of the term, Abby acknowledges how much she has learned in the past few months. She calls the journey "My Age of Enlightenment." While recognizing how she still holds fast to her earlier hopes and aspirations as a teacher, she also reflects on how she has changed:

But a significant change is that I have engaged my own voice, incorporating advice from those I admire while finding the person I want to be as a teacher, and realizing that who I am is exactly who I need to be. (Credo, November 30, 2009)

There is a new-found sense of confidence in Abby. Concerned about creating a classroom that is cooperative and inclusive, a classroom where students are not pulled out to receive additional assistance from resource teachers, Abby (Credo, November 30, 2009) proposes that teachers need to engage in "open and productive communication" and "an openminded cooperative style” among teachers in order to facilitate integrated learning.

As Abby reflects on the first semester of her teacher education program, she knows that she is becoming pedagogical, and perhaps the most startling epiphany is that she has learned how becoming a teacher begins with a sense of personal identity, "bringing me to understand who I needed to be as a teacher":

It was a long journey to realize that it is exactly who I am and the experience that I bring, which makes me unique as a teacher. The hours of reflections and assignments from all of my classes seemed to settle over me in an enlightening moment of what the program was trying to elicit from me. It wasn't just to learn the mechanics of teaching, but to learn who we are as persons, as role models, and to decipher what knowledge we bring to the classroom and how to use it effectively. (Credo, November 30, 2009)

Rather than performing the role of a teacher, or separating the personal self from the professional self, we have to enhance our teaching with who we are and what we are passionate about. Although this is a life lesson that I have learned before, somehow it seemed that being a teacher required a different and more daunting set of standards. I believe that if I show my students that I truly care about them as people, while sharing myself and my passion for life and literature, then I can create and nurture a love for reading and writing that will stay with them long after they leave my classroom. (Credo, November 30, 2009)

\section{Bridget's Credo}

At the beginning of the semester, Bridget wrote about her past: 
I was ejected from two high schools back in the 70's. My pedagogy at this early point is focused on those like myself, when I was actually attending high school, that may be at risk of falling through the cracks as I did. (Credo, September 14, 2009)

Bridget remembers herself as an adolescent artist: "I could draw and paint and write but everyone thought I was neurotic because of the things I wrote about, painted, and drew." Based on her experiences as a student in school, Bridget now hopes, as a teacher, to foster in the classroom "a sense of love and respect for and within my students”:

So as a teacher I would hope to invest myself as much as possible in the lives and experiences of my students and attend to my lesson plan accordingly, incorporating what I have learned and will continue to learn within this next year and till I die. To try to prevent those like myself from becoming discouraged or worse-bored. To inspire. To encourage. To never give up on even one-because that would have been me. (Credo, September 14, 2009)

In the middle of the semester, Bridget (Credo, October 19, 2009) continued to reflect on her past experiences in school, and though she quit high school before graduating, she remembers a Grade 11 English teacher who inspired her with creative options that invited her to use her artistic gifts: "This teacher gave me a sense of worth that remained with me when I felt profoundly worthless.” Bridget understands well how the process of becoming pedagogical is integrally connected to past experiences:

My identity comes from my own history. My education has opened my world and the most important thing I have learned is that I am not alone. If I can pass on this gift to a student, this validation, this self-worth and the sense that they are not alone in the world and that they too can persevere, I will consider myself a teacher. (Credo, October 19, 2009)

She now understands that her credo for teaching includes the promotion of "acceptance, tolerance, creativity."

In her final credo statement for the semester, Bridget surmises, "The question is not what to teach, it is how." She expands on some of the themes that she began to address in her earlier writing: "I believe that for all the theory and strategies we've been taught, the students themselves will dictate much of how we teach.” Instead of being "concerned about what to teach" since "one can access this information quite easily with a quick Google search," Bridget now understands how "the tricky part is the method; the 'how", because "ultimately, success will depend on how well a teacher is paying attention to their students." Bridget wisely confesses: "I am tempted to stand at the front of the class and simply ask them what they'd like to know." She asks: "Which path do I lead them towards, so that they can then recognize and make connections specific to their experiences?” (Credo, November 30, 2009)

As Bridget completes the first term of her Bachelor of Education program, she writes: 
I think I will be okay. In retrospect, I think one of the reasons I quit high school is that I was not given the opportunity to make the connections that I had in mind. Moreover, I think perhaps I was making connections, but they were the ones neither expected nor accepted by my teachers at the time. This was in the early 1970's. I remember drawing large spiders on a big piece of flipchart paper for an Art class. The teacher recommended that I see a psychiatrist. I didn't think there was anything wrong with me at the time. I have always had an artistic eye and had just discovered an excellent line form to depict the body and legs of a spider. I also remember drawing the profile of a person's face. I had done this by running my finger from my own forehead to my chin. The teacher, however, accused me of tracing my profile from a magazine and chastised me in front of the class. I was insulted. This act of discovery repeated itself in other subjects. I could find a metaphor in everything I read and tried to voice my discoveries only to be told that I was either missing the point or being deliberately uncooperative. (Credo, November 30, 2009)

As Bridget continues to reflect on her experiences as an adolescent in school, and as a lifeguard instructor, she grows more confident that teaching is connected to the places you have been and to the stories you have lived and the identities that you have adopted:

With teaching, it is not as much what you say, but how you say it, in what context and with what tone of voice, that will increase the odds of effectively get the point across. Again, the point I come back to, is not the what, but the how of teaching that is what is needed in order to allow the students to use their own brains, their own experiences, their own imaginations in order to learn more than they did before they walked into my classroom. (Credo, November 30, 2009)

For Bridget, becoming pedagogical is a process that teachers and learners engage in together.

\section{Cynthia’s Credo}

At the beginning of the semester, Cynthia took up my (Carl's) invitation to consider herself an a/r/tographer. She wrote:

I am looking forward to learning all that I can in order to be a great teacher. My hope is that I can learn the tools to encourage students to think creatively and critically. I love this idea of being an a/r/tographer. I know I am an artist in the sense of my work in the theatre, but I also love to take photos, paint just about anything, and I have even written a few poems. As a researcher, I am a continual learner and a Googler. The path that lead me here actually came through my research in directed theatre studies which involved drama as education and drama as therapy. I am here to develop my skills as a teacher and this includes a better understanding of how to be an a/r/tographer. (Credo, September 14, 2009)

Following her 2-week practicum, Cynthia wrote about the process of becoming pedagogical by focusing on the pedagogical relationship between the educator and the 
learner. She is especially concerned about "the structure of school," including the dilemma of time in the classroom:

A creative process in any sense takes time, more time than is possible in the present system. I struggle because I am unable to give students enough of my time, enough time and space to develop skills to write, to act, and to create. Maybe what makes this so difficult is because I know there needs to be changes made, but what is the next step? What can I do? How is change possible? (Credo, November 9, 2009)

A cornerstone of Cynthia's credo is that "each student comes with a different life story and is looking to be a part of a community in some way." In order to foster a sense of community, Cynthia advocates the value of preparation:

For now what I can bring as a teacher to the classroom is to be prepared. In thinking of ways that I can be prepared, there is a motto which I created for myself that has been helpful. I try to keep the following in mind; to be positive, proactive and personable. I affectionately call these the 3 Ps. I find that if I can keep these concepts a priority, I am prepared for my day and better able to be an encouragement or a help to another. (Credo, November 9, 2009)

In addition to promoting preparation as important for nurturing community in the classroom, Cynthia hopes "to create a positive environment" for her students by developing "a safe and comfortable atmosphere" where "trust and respect" are enjoyed by everyone, and where everyone is encouraged "to ask questions." Above all, Cynthia hopes to create opportunities for students to "grow, create, and discover what is in their hearts" (Credo, November 30, 2009).

\section{Doreen's Credo}

At the beginning of her journey of becoming pedagogical, Doreen was eager to articulate a clearer understanding of her personal philosophy about teaching and learning:

There is an interconnectedness between emotion and learning. So, education is as much about the emotional experience that students are going through at any given stage in their educational career as it is about the curriculum that they are learning. I feel a strong empathy to the emotional experiences of adolescents. (Credo, September 14, 2009)

Out of an abiding personal "sense of justice” Doreen is committed to creating "a classroom environment of flexibility and equality, rather than discrimination and rigidity.” At the same time she is aware of the challenges that characterize teaching:

The realization that often times, you don't have the time or space to fully realize your credo. That your ideas are idealistic. That you are going to be constantly challenged, constantly fighting against so many factors that would see you beaten down. Realizing that you may never be able to help every student you want to, that you may have to watch a young person leave your life knowing that you could have maybe helped them in some small way, but for a million reasons, you couldn't, and you have to hold that knowledge in your heart. Knowing the 
struggle and feeling the pain that a student may experience, and never being able to know what to do with those empathic feelings of relativity, but still feeling the pain. (Credo, September 14, 2009)

Throughout the semester, Doreen continued to develop and express her convictions about teaching:

I believe in leading by example. One of the most important aspects of teaching is embodying the skills and traits that you hope to instil in your students. I believe that students will be more respectful towards, and more inclined to learn ideas and skills if they are actively practiced and demonstrated by their teacher. Everything from critical thinking to treating other perspectives with respect and being open to new ideas are best taught through example. A philosophy of leading by example is especially important to me as I see more and more that high school students are completely unique. (Credo, November 9, 2009)

Doreen's commitment to "leading by example" resonates with the etymology of education, educare, to lead out. Doreen acknowledges the complex, and often chaotic, contexts of school teaching, and she holds out hope that a teacher who is focused on creatively and heartfully connecting with learners will shape classroom experiences where care, cooperation, and community can be nurtured:

I believe that it is extremely important to maintain a sense of empathy for the tumultuous, confusing, difficult time of development and change that is the teenage experience. It is important to plant the seeds of education in students, and teachers may not always be in their students' lives long enough to see those seeds flower, but setting an example can plant a positive seed somewhere in a student's experience, and this is often times one of the important parts of being a teacher. (Credo, November 30, 2009)

\section{Esther's Credo}

Esther evoked the experience of many beginning teacher candidates with her observation that "the idea of my becoming an English teacher is both exhilarating and scary." She is convinced that she will become an effective teacher if she is committed to living with "patience, passion, empathy, as well as a genuine interest for my students." As a theatre and drama major, Esther promotes theatre and literature for inviting "creative and engaging ways to investigate human conditions." Also, she anticipates that her "positive, nurturing and enthusiastic" personality will serve well in gently guiding students in their pedagogic adventures. Esther is eager to promote students' voices and critical thinking. She is concerned about past experiences in school where the teacher precluded any questioning by insisting that he already knew the correct answers: "He marked everyone as wrong when they did not come up with his answer." Another teacher was more a preacher than a teacher. Esther is committed to creative and critical thinking that invites conversations in the context of communities of teaching and learning.

Based on her past personal experiences and beginning experiences in the teacher education program, Esther was convinced that engaging her students is crucial: 
In order to engage them I need to make the curricula relevant to them, fit their learning styles and most importantly fun. If a student does not think what they are learning is relevant or fun then they will have no interest in learning the material. I believe as an English teacher I have an unlimited amount of literature available to me. I need to make sure what I present to the students will provoke them to learn. Using multiple teaching styles is also important as that is how I can reach the different types of learners in any given class. By incorporating group work, drama or role playing, individual work and many other forms of learning and teaching I will make the class a more vibrant and exciting place to be. As important as spelling, grammar or Shakespeare may be, if students are not interested in what they are learning then results such as poor attitudes, grades and minimal learning will occur. If these things can be incorporated into a fun learning style, then students will be much more receptive. I believe that if I think what I am teaching is engaging then the students probably will as well. If I am bored then the students are definitely not learning anything. (Credo, November 30, 2009)

\section{Conclusion}

In Teaching in the Knowledge Society: Education in the Age of Insecurity, Hargreaves (2003) proposed that we educators need to address with forthright courage and thoughtful creativity "how we should live our lives, and for what kind of life we should be educating young people” (p. 48). After ruminating on teacher qualities and dispositions such as flexibility, problem-solving, risk-taking, continuous improvement, cosmopolitan identity, and personal and professional maturity (pp. 29, 65-66), Hargreaves (2003) concludes that "engaging with the knowledge society and its human consequences calls on us to make teaching into a social mission and a creative, passionate profession once again” (p. 203). We think that most teachers have always held fast to the sense of teaching as a vocation that is located in what Hargreaves (2003) calls "a social mission and a creative, passionate profession”(p. 203). Certainly, this focus on teaching as transformative, creative, and passionate is expressed eloquently and compellingly in the writing of the teacher candidates included in this research project.

In an intriguing essay Teacher as Poet, Berman (1999) discusses five qualities that she claims are "pertinent to the poet and poetry" and that she believes "may characterize the teacher and teaching. These qualities include: (a) giving voice to the unspoken, (b) befriending mystery, (c) connecting heart/mind conversations, (d) bearing witness, and (e) delighting in surprise” (p. 18). If a teacher education program focused on the concept of the "teacher as poet" (or the teacher as artist, etc.), what would that program look like, sound like, feel like, be like, become like?

In our becoming pedagogical study, the dispositions of the teacher candidates resonated with Berman's suggested qualities. We offer the following examples of how our teacher candidates enacted the qualities she outlined through their living, inquirybased credos: (a) giving voice to the unspoken by bringing one's passion for life to teaching, (b) befriending mystery by sharing creative gifts between teachers and students, (c) connecting heart/mind conversations by thinking creatively and critically, (d) bearing witness by creating classroom experiences that exemplify care, cooperation and 
community, and (e) delighting in surprise by creating a vibrant learning environment with patience, passion and empathy. Interpreting these qualities with the credos of teacher candidates - of teachers who are also artists - offers us a glimpse into the potential of what a teacher education program could look like, sound like, and feel like as we focus our efforts on learning to learn or becoming pedagogical.

According to Feiman-Nemser (2008), there are four broad themes under which learning to teach may be conceptualized: "learning to think like a teacher, learning to know like a teacher, learning to feel like a teacher, and learning to act like a teacher" (p. 698). Admittedly, all four are important. However, what we have come to appreciate most deeply in this study is that learning to feel like a teacher is essential to learning to learn or to becoming pedagogical. Teaching and learning are profoundly personal as teachers' engage emotionally with the creation of their identities as educators. They create personal visions as hopeful affirmations that despite the possibility of heartbreak, opens their hearts to the possibility of making a significant difference in the lives of others. As Day (2005) notes, “A passionate teacher can never, by definition, be resigned to the status quo. Yet hope, the bedrock of passionate teaching, can be hard to sustain” (p. 19). By integrating credos as a pedagogical strategy within a teacher education course, we remain hopeful that the teacher candidates' passion and commitment to teaching has been creatively engaged and personally nurtured. In retrospect, we also recognize that my (Carl's) credo might be held up as a passionate marker for teacher candidates committing to a lifetime of envisioning and re-envisioning one's commitment and passion for the vocation of teaching. If we want to encourage passion in the teaching of our students, we need to share our own passion for teaching and learning. In essence, we, as teacher educators, have to demonstrate for one another how credos evolve over time, as our passions, insights, and emotional connections ebb and flow.

Credos proved to be one strategy to explore how teaching is a creative profession for our teacher candidates and for us as instructors. Teacher candidate credos not only illustrate their passions, beliefs and desires toward their practice, but also they guide us as teacher educators as we create programs attentive to teacher candidate interests. Teacher candidates genuinely want to have an impact on students. By concentrating on sustaining their hearts as teacher candidates, we are leading the way to sustaining their hearts as they enter the profession. Lastly, and perhaps more importantly, they are engaging in learning to learn and they are learning to feel like teachers through an $\mathrm{a} / \mathrm{r} /$ tographic living inquiry experienced in and through time. In sustaining our hearts by becoming pedagogical, we live our lives through writing and rewriting our credos where our identities, stories, and hopes all circulate in the ways of the heart's rhythms-integral, connected, and vital. 


\section{References}

Berman, L. M. (1999). Teacher as poet. Theory into Practice, 38(1), 18-23.

Britzman, D. (2003). Practice makes practice: A critical study of learning to teach. New York, NY: SUNY Press.

Bullough, R. V. Jr., (2006). Developing interdisciplinary researchers: What ever happened to the humanities in education? Educational Researcher, 35(3), 3-10.

Cooper, K., \& White, R. E. (2004). Burning issues: Foundations of education. Lanham, MD: Scarecrow Education.

Crosswell, L. (2006). Understanding teacher commitment in times of change. Unpublished Doctor of Education dissertation, Queensland University Technology, Australia.

Day, C. (2000). Stories of change and professional development: The costs of commitment. In C. Day, A. Fernandez, T. Hauge, \& J. Moller (Eds.), The life and work of teachers: International perspectives in changing times (pp. 109-129). London, UK: Falmer Press.

Day, C. (2005). A passion for teaching. London, UK: Routledge Falmer.

Day, C. (2008). Committed for life? Variations in teachers' work, lives and effectiveness. Journal of Educational Change, 9, 243-260.

Feiman-Nemser, S. (2008). Teacher learning: How do teachers learn to teach? In Cochran_Smith, M., Feiman-Nemser, S., McIntyre, D. J., \& Demers, K. E. (Eds.). Handbook of research on teacher education: Enduring questions in changing contexts ( ${ }^{\text {rd }}$ ed., pp. 697-705). New York, NY: Routledge.

Flaum, L. S. (1959). A credo for teachers. Journal of Teacher Education, 10(4), 422-424.

Freire, P. (1993). Pedagogy of the city. (D. Macedo, Trans.). New York, NY: Continuum.

Hargreaves, A. (2000). Four ages of professionalism and professional learning. Teachers and Teaching: Theory and Practice, 6(2), 151-182.

Hargreaves, A. (2003). Teaching in the knowledge society: Education in the age of insecurity. New York, NY: Teachers College Press.

Leggo, C., Sinner, A., Irwin, R., Pantaleo, K., Gouzouasis, P., \& Grauer, K. (2010). Lingering in liminal spaces: A/r/tography as living inquiry in a language arts class. International Journal of Qualitative Studies in Education, 24(2), 239-256.

Meijer, P. C., de Graaf, G., \& Meirink, J. (2011). Key experiences in student teachers’ development. Teachers and Teaching, 17(1), 115-129.

Palmer, P. J. (1998). The courage to teach: Exploring the inner landscape of a teacher's life. San Francisco, CA: Jossey-Bass. 
Rogers, G. (2011). Learning-to-learn and learning-to-teach: The impact of disciplinary subject study on student-teachers' professional identity. Journal of Curriculum Studies, 43(2), 249-268.

Sawyer, R. K. (2004). Creative teaching: Collaborative discussion as disciplined improvisation. Educational Researcher, 33(2), 12-20.

Springgay, S., Irwin, R., Leggo, C., \& Gouzouasis, P. (Eds.). (2008). Being with a/r/tography. Rotterdam, NL: Sense Publishers.

\section{Endnotes}

${ }^{1}$ Other assignments in the course concentrated on curriculum planning in preparation for their extended practica.

${ }^{2}$ Each of the participants consented to participating in the study. Their credos were collected and analyzed after the completion of the year-long program. Moreover, their identities are masked here through the use of pseudonyms.

${ }^{3}$ Some sections are longer than others are because each teacher candidate wrote more or less. 